\title{
Re-Os isotope systematics of sulphide inclusions in diamonds from Victor (Superior craton) document mobilisation of volatiles and Os during Rodinia break-up
}

\author{
Sonja Aulbach ${ }^{1,2}$, Robert A. Creaser ${ }^{1}$, Thomas Stachel ${ }^{1}$, Ingrid Chinn ${ }^{3}$, Julie Kong ${ }^{4}$ \\ ${ }^{1}$ University of Alberta,Edmonton AB, Canada, s.aulbach@em.uni-frankfurt.de,rcreaser@ualberta.ca, \\ tstachel@ualberta.ca \\ ${ }^{2}$ Goethe University, Frankfurt am Main, Germany. \\ ${ }^{3}$ De Beers Exploration, Southdale, South Africa,Ingrid.Chinn@debeersgroup.com \\ ${ }^{4}$ De Beers Canada, Toronto, Canada, Julie.Kong@debeersgroup.com
}

\section{Introduction}

The James Bay area on the Superior Craton hosts both Mesoproterozoic kimberlites ( 1.1 Ga; Kyle Lake) and Jurassic kimberlites ( 180-170 Ma; Attawapiskat, including Victor; Januszczak et al. 2013) in close proximity (separated by $\sim 100 \mathrm{~km}$ ). A major thermal event related to the development of the Midcontinent Rift at ca. 1.1 Ga induced an elevated regional geothermal gradient that led to partial diamond destruction (Smit et al. 2014a,b). The Victor kimberlite is characterised by an inclusion suite that, contrary to the the current paradigm, formed in a moderately depleted lherzolitic mantle and produces diamonds of exceptional value (Stachel et al., this volume). This raises the question of when, and how, the diamond inventory at this locality was formed. Based on a comparison of $\mathrm{N}$ aggregation and carbon isotope systematics of diamonds from the two kimberlite age groups, it was hypothesised that the Victor kimberlite sampled a young generation of diamonds which formed after dissipation of the heat associated with the Midcontinent Rift (Smit et al. 2014a). Given that the lherzolite-dominated Victor suite represents an unconventional diamond deposit (Stachel et al., this volume), age dating is required to confirm the timing of this inferred young diamond-formation event. This not only allows us to establish a link to regional tectonothermal evolution, but also to explore broader implications for models of diamond formation and the associated carbon redistribution in the lithospheric mantle as part of the deep carbon cycle.

Sulfides are known to be the main hosts to highly siderophile elements, among them Re (including the radionuclide ${ }^{187} \mathrm{Re}$ ) and Os (including the radiogenic isotope ${ }^{187} \mathrm{Os}$ ), and therefore lend themselves to the determination of single-sulfide Re-Os isotope systematics (Pearson et al. 1998). During strong melt depletion, the mildly incompatible element Re preferentially partitions into the melt, whereas the compatible element Os remains in the residue (Shirey and Walker 1998). Thus, the Re-Os isotope system is particularly well-suited to date the cratonic lithospheric mantle, which formed by extraction of high degrees of melt. We studied a suite of peridotitic sulphide inclusions in diamonds from the Victor Main and Victor South kimberlites for major elements, by Scanning Electron Microprobe (SEM), and Re-Os isotope systematics, by Isotope Dilution Negative Thermal Ionisation Mass Spectrometry (ID-NTIMS), in order to obtain constraints on the nature of their source rocks and formation ages.

\section{Geological Background and Prior Work}

The Jurassic ( 180-170 Ma) Attawapiskat kimberlites, including Victor, erupted in the Superior craton, near the boundary between the Palaeoarchaean Northern Superior and the Mesoarchaean North Caribou superterranes. Following cratonisation at ca. $2.7 \mathrm{Ga}$, the area was affected by a major thermal event related to the Midcontinent Rift to the south. Refertilisation in the course of rifting has been suggested (Smit et al. 2014b), although its timing remains unknown. Rifting, however, lead to destruction of older generation(s) of diamond. This is evidenced by (1) an elevated geothermal gradient recorded in mantle xenocrysts from the nearby ca. 1.1 Ga Kyle Lake kimberlites (coresponding to a surface heat flow of $40-41 \mathrm{~mW} / \mathrm{m}^{2}$ ), and (2) the presence at that time of of lithospheric diamonds with highly aggregated $\mathrm{N}$, which are largely absent from the younger 
kimberlites (Smit et al. 2014a,b). The latter record a return to cooler conditions $\left(39 \mathrm{~mW} / \mathrm{m}^{2}\right.$ ) and a widening of the diamond window from 140-180 km depth to 120-200 km depth (Smit et al. 2014a).

\section{Samples and Analytical Techniques}

To constrain the timing of diamond formation beneath Victor, 20 visually crack-free diamonds were broken to retrieve 20 sulphide inclusions in the De Beers Lab at the University of Alberta. Semiquantitative analysis by SEM was used to assign a paragensis based on $\mathrm{Ni} / \mathrm{Fe}$, showing that 19 stones contained one to two Peridotitic-type sulfide inclusions and one contained multiple Eclogitic-type sulfide inclusions. Of these, the best specimens in terms of size and/or completeness were selected for processing, which included addition of a mixed Re-Os spike, dissolution, purification of Os by distillation and of Re by anion microcolumn chromatography. Purified Re and Os fractions were analysed by negative TIMS on a Micromass Sector 54 mass spectrometer, operated by single collector peak-hopping using an ETP electron multiplier (pulse counting mode) at the Radiogenic Isotope Facility (University of Alberta). Osmium and Re blanks were very low, averaging $6 \pm 3 \mathrm{fg}$ and $200 \pm 50$ $\mathrm{fg}$, respectively. A $1 \mathrm{pg}$ load of the in-house Os standard (AB-2) yielded an accurate ${ }^{187} \mathrm{Os} /{ }^{188} \mathrm{Os}$ ratio, indistinguishable from larger loads measured with Faraday collectors.

\section{Results and Age Dating}

Peridotitic sulphides have Ni/Fe ratios ranging from 0.37 to 0.77 , Re contents from $\sim 19 \mathrm{ppb}$ to $\sim 18$ ppm and Os contents from $360 \mathrm{ppb}$ to $\sim 860 \mathrm{ppm}$. This translates into ${ }^{187} \mathrm{Re} /{ }^{188} \mathrm{Os}$ from 0.0014 to 8.7 (compared to 0.422 for Primitive Upper Mantle, PUM), while ${ }^{187} \mathrm{Os} /{ }^{188} \mathrm{Os}$ range from 0.1171 to 0.2255 (unradiogenic relative to PUM, with present-day ${ }^{187} \mathrm{Os} /{ }^{188} \mathrm{Os}$ of 0.1283 , to radiogenic).

Given evidence for the formation of diamond in peridotite substrates with non-primitive initial ${ }^{187} \mathrm{Os} /{ }^{188} \mathrm{Os}$, combined with the fertile nature of lithospheric mantle beneath Attawapiskat at the time of Victor kimberlite emplacement, which indicates a multi-stage evolution of the mantle source, Redepletion or mantle model ages are likely to be meaningless (Aulbach et al. 2016). Indeed, mantle model ages $\left(\mathrm{T}_{\mathrm{MA}}\right)$, calculated assuming formation from a primitive mantle source (PUM), range from ca. 3.2 Ga to future ages. Rhenium depletion ages, which are minimum ages, may be calculated from samples with unradiogenic Os. They, too, rely on assumptions about the mantle source, and range from 1.2 to $1.7 \mathrm{Ga}$. A regression through all data shows a good correlation $\left(\mathrm{r}^{2}=0.96\right)$, but also some scatter. Excluding two obvious outliers, the correlation is improved to $r^{2}=0.99$. Regression through these data $(\mathrm{n}=14)$ yields a $718 \pm 49$ Ma model 3 isochron (MSWD 6.1), with an initial ${ }^{187} \mathrm{Os} /{ }^{188} \mathrm{Os}$ of $0.1177 \pm 0.0016$, i.e. unradiogenic (depleted) at the time of formation.

\section{Discussion and implications}

To our knowledge, this is the first model 3 isochron obtained from cratonic peridotitic material that yields an unradiogenic initial Os isotopic composition, pointing to formation or rehomogenisation in a depleted mantle source. The ca. 720 Ma diamond formation age corresponds to rifting at the craton margin during Rodinia break-up and suggests remobilisation of volatile-rich components due to attendant mantle stretching. Such components may have been emplaced during earlier metasomatism, e.g., related to the ca. $1.1 \mathrm{Ga}$ Midcontinent rift. Olivine separates from peridotite xenoliths reveal the mantle beneath Victor to contain regions with both highly unradiogenic and radiogenic Os $(0.1012$ to 0.1821 ), reflecting various degrees of melt extraction during cratonic lithosphere formation and subsequent metasomatic enrichment (Smit et al. 2014b). In this light, we interpret the quasiisochronous behaviour of sulphides in the peridotitic Victor diamond suite to reflect mobilisation of fluid during continental break-up, in amounts sufficient to largely re-homogenise the - by that time isotopically highly variable Os. The presence of two outliers and scatter in the remaining samples (indicated by the MSWD of $\sim 6$ ) indicates that re-homogenisation was incomplete.

The diamond-forming metasomatic event may have prompted co-precipitation of sulphides and their host diamonds, for example from an $\mathrm{H}_{2} \mathrm{~S}$-bearing melt reaching sulphide saturation. Alternatively, the 
fluids catalysed recrystallisation - accompanied by isotopic rehomogenisation - of protogenetic sulphides that were reintroduced into the depleted lithosphere during ca. 1.1 Ga refertilisation postulated by Smit et al. (2014b), and which served as a reduction agent for initial diamond crystallisation from a carbonated fluid (Palyanov et al. 2007). This latter interpreation appears consistent with evidence for the oxidising nature of metasomatic fluids (Woodland and Koch 2003), in particular in association with rifting and lithosphere rejuvenation (Foley 2011). In addition, involvement of a carbonated melt seems possible, based on the shallow cratonic lithosphere depth ( 150-160 km; Stachel et al., this volume) from which silicate-included Victor diamonds were derived, where relatively high oxygen fugacities permit the coexistence of carbonate-rich melts with diamond (Stagno et al. 2015). Such oxidising fluids would be able to scavenge more Re than Os (Aulbach et al. 2016), leading to crystallisation of sulphides with comparatively high Re/Os that, following encapsulation in diamond, evolved to correspondingly high measured ${ }^{187} \mathrm{Os} /{ }^{188} \mathrm{Os}$, as observed for the Victor sulphide inclusion suite.

Peridotitic sulphide-included diamond formation beneath Victor at ca. $720 \mathrm{Ma}$ demonstrates that volatile remobilisation has taken place in the context of supercontinent reorganisation. Thus, incipient rift settings not only are prospective with respect to diamond formation, but they are also important sites of volatile focusing and redistribution.

\section{References}

Aulbach S, Mungall JE, Pearson DG (2016) Distribution and Processing of Highly Siderophile Elements in Cratonic Mantle Lithosphere. In: Harvey J, Day JMD (eds) Highly Siderophile and Strongly Chalcophile Elements in High-Temperature Geochemistry and Cosmochemistry, vol 81. pp 239-304

Foley SF (2011) A Reappraisal of Redox Melting in the Earth's Mantle as a Function of Tectonic Setting and Time. J Petrol 52(7-8):1363-1391

Januszczak N, Seller MH, Kurszlaukis S, Murphy C, Delgaty J, Tappe S, Ali K, Zhu J, Ellemers P (2013) A Multidisciplinary Approach to the Attawapiskat Kimberlite Field, Canada: Accelerating the Discovery-to-Production Pipeline. Proceedings of the $10^{\text {th }}$ International Kimberlite Conference, vol 2:157-171

Palyanov YN, Borzdov YM, Bataleva YV, Sokol AG, Palyanova GA, Kupriyanov IN (2007) Reducing role of sulfides and diamond formation in the Earth's mantle. Earth Planet Sci Lett 260:242-256

Pearson DG, Shirey SB, Harris JW, Carlson RW (1998) Sulphide inclusions in diamonds from the Koffiefontein kimberlite, S Africa: constraints on diamond ages and mantle Re-Os systematics. Earth Planet Sci Lett 160:311-326

Shirey SB, Walker RJ (1998) The Re-Os isotope system in cosmochemistry and high-temperature geochemistry. Ann Rev Earth Planet Sci 26:423-500

Smit KV, Stachel T, Stern RA (2014a) Diamonds in the Attawapiskat area of the Superior craton (Canada): evidence for a major diamond-forming event younger than $1.1 \mathrm{Ga}$. Contrib Mineral Petrol 167(1)

Smit KV, Pearson DG, Stachel T, Seller M (2014b) Peridotites from Attawapiskat, Canada: Mesoproterozoic Reworking of Palaeoarchaean Lithospheric Mantle beneath the Northern Superior Superterrane. J Petrol 55(9):1829-1863

Stachel T, Banas A, Aulbach S, Smit KV, Wescott P, Chinn I, Fisher D, Kong J (2017) The Victor Diamond Mine (Superior Craton, Canada) - A new paradigm for exploration in unconventional settings. In: 11th International Kimberlite Conference, vol., Gaborone, Botswana

Stagno V, Ojwang DO, McCammon CA, Frost DJ (2013) The oxidation state of the mantle and the extraction of carbon from Earth's interior. Nature 493:84-88

Tappe S, Foley SF, Stracke A, Romer RL, Kjarsgaard BA, Heaman LM, Joyce N (2007) Craton reactivation on the Labrador Sea margins: Ar-40/Ar-39 age and Sr-Nd-Hf-Pb isotope constraints from alkaline and carbonatite intrusives. Earth Planet Sci Lett 256:433-454

Woodland AB, Koch M (2003) Variation in oxygen fugacity with depth in the upper mantle beneath the Kaapvaal craton, Southern Africa. Earth Planet Sci Lett 214:295-310 